\title{
A COMPARATIVE EVALUATION OF MUNICIPAL SOLID WASTE LANDFILL SITES IN NORTHERN IRAN
}

\author{
YAZDANI, M. ${ }^{1}$-MONAVARI, S. M. ${ }^{1 *}$-OMRANI, G. A. ${ }^{2}$-SHARIAT, M. ${ }^{1}$-HOSSEINI, S. M. ${ }^{3}$ \\ ${ }^{I}$ Department of Environmental Science, Faculty of Environment and Energy, Tehran Science \\ and Research Branch, Islamic Azad University, Tehran, Iran \\ ${ }^{2}$ Tehran University of Medical Sciences, School of Public Health, Tehran, Iran \\ ${ }^{3}$ Department of Forestry, Faculty of Natural Resources, Tarbiat Modares University, Noor, Iran \\ *Corresponding author \\ e-mail: Monavari2015@yahoo.com
}

(Received $16^{\text {th }}$ Jan 2017; accepted $2^{\text {nd }}$ Jun 2017)

\begin{abstract}
Not only in developing countries has remained land-filling the most customarily used method despite the increased attention to development of the Municipal Solid Waste (MSW) management. There is a worldwide need to find the right management of MSW and this research is developing an strategy for landfill sites in Iran. We first determine the characteristics of the ten landfill sites in western part of Mazandaran province, northern Iran, using seven different landfill site sitting approaches. After reviewing each waste deposit site, considering all the criteria in each one of the seven methods applied in the present study, the incoherence in suitability was apparent in first phase. The second phase was to address the locally preferred criteria for landfill site evaluation. The aims of the present research were to show the unsuitability of the current landfill sites in western part of Mazandaran province and therefore, addressing locally preferred criteria for landfill site evaluation in northern Iran, commonly referred to as the Caspian Landfill Criteria (CLC), using which the most suitable areas for landfill sites were formerly chosen. The most principal parts in the CLC model were the importance of the weights of the criteria and the preferred weights of them. This model with eighteen effective and native criteria provides the suitable evaluation technique for municipal landfill sites. The final aim of this project was to apply the obtained results to illustrate the lack of suitable regions for MSW landfill sites in studied area.
\end{abstract}

Keywords: Evaluation method, Caspian Landfill Criteria, Iran, GIS, AHP

\section{Introduction}

During the last decade improvements about how to manage the solid waste in the cities was developed. Landfills have been a quick and efficient solution but still there are many improvements to be done (Adamcová et al., 2016; Cassinari et al., 2016; Chen et al., 2015; Wong et al., 2016a, 2016b). Solid waste management is a challenging issue (Guerrero et al., 2013) as waste disposal in developing countries is one of the significant environmental challenges (Baun and Christensen, 2004; Sharholy et al., 2008). Waste generation has grown rapidly over the recent years in Iran. It has been shown that new capabilities and capacities are required to address the crisis of growing waste production in Iran, as well as new disposal centres. The location of a disposal centre is an important factor, which should be considered in construction of any new centre (Shahabi, 2008). Although, the municipal solid waste (MSW) management has been developed worldwide, it is still in a critical status in Iran (Abdoli, 2005; Yazdani et al., 2013). In most Iranian cities, landfills are not used. About less than $50 \%$ of the municipal solid waste disposal methods in Iranian cities is still confined to pile-up or other unsafe methods of disposal (Rahim et al., 2005). Open dumping is a common method of waste 
disposal in most Iranian cities (Yazdani et al., 2015a). Numerous problems are seen in the landfill sites in Iran including those in Mazandaran province. Open-air waste burning, open-pit dumping and unsafe disposal considerations are common procedures in this province which can result in irreparable damages in the environment and also on society health (Yazdani et al., 2013 and 2015a; Calvo et al., 2005; Calvo et al., 2007; Diaz et al., 2005). Some land degradations caused by landfills have been previously reported, for instance, the impacts of landfills on soil quality. It has been shown that the leachate from landfills causes the soil degradation (Hernandez et al., 1998; Raman and Narayanan, 2008; Shaylor et al., 2009). The important environmental problems affiliated with open dumps are the infiltration and ground water pollution and the subsequent contamination of the land (Kale et al., 2010; Fatta et al., 1999). The leachate from municipal solid waste (MSW) landfills is a chemical compound. Therefore, small amounts of leachate can pollute soil which can contaminate a large amount of groundwater (Nema et al., 2009; Dimitriou et al., 2008; Mor et al., 2006). For example, leachate changes the nitrate level of soil. Nitrates are easily transported with water and therefore it pollutes surface and subsurface waters (Novara et al., 2013). Uncontrolled waste incineration resulted from the degradation process is one of the other important issues in the open dumping sites (Yazdani et al., 2015b). In the present studied area, uncontrolled waste incineration is the common process in most of the 10-landfill sites. Some studies have reported the negative impacts of the fire, resulted from waste incineration, on soil quality by affecting the chemical and microbiological properties of the soil (Martínez-Murillo et al., 2016; Pereira et al., 2016) In natural ecosystems, such as existing landfill sites in the studied area, restoration of the degraded soil is achieved by returning the microbiota activity and plant community recovery. Soil development is dependent on the erosion severity, total nitrogen and $\mathrm{pH}$ (Yazdani et al., 2015b), since these parameters in soil texture is determined the soil typicality (Pallavicini et al., 2014).

Therefore, the attempt of the present study was to understand the quality of existent landfill sites. During the last decades multiple methods have been applied to develop more suitable municipal solid waste landfill sites. Some relevant studies have integrated GIS with MCDA (Multi Criterai Decision Making) on landfill site sitting in several procedures, some of which are mentioned below.

Alanbari et al. (2014) and Sureshkumar et al. (2017) have used Multi Criteria Decision Analysis and GIS for municipal solid waste landfill site sitting. Elahi et al. (2014) have applied Multi Criteria Decision Analysis after preparing the data and evaluating the criteria according to the geographic situation of the studied area and have overlaid the map layers with the relevant criterion in ArcGIS. This recent study finally presented 3 places in Tafresh city for municipal landfill site sitting.

Moeinaddini et al. (2010) have used spatial cluster analysis (SCA) method and weighted linear combination (WLC) to choose the proper options for MSW landfill site in Karaj city. The most preferred site was then identified by Analytical Hierarchy Process (AHP). This study has indicated that WLC was useful for identification of the criteria and AHP was useful for prioritization.

In another research carried out by Eskandari et al. (2012) a methodology based on socio-cultural and economical-ecological aspects using multi criteria evaluation integrated with GIS has been suggested to choose a proper MSW landfill site in Marvdasht city. Delgado et al. (2008) have presented three spatial analysis models (overlay analysis, Boolean logic, binary evidence) for MSW landfill site sitting. 
Furthermore, available MSW landfills are evaluated by some procedures, such as Monavari 95-2 (Monavari and Shariat, 2000; Farzaneh, 2003; Ghanbari et al., 2011), Oleckno method (Salimi et al., 2013; Monavari and Arbab, 2005), Drastic (Wang, 2007), USEPA method (Christensen, 1992) and regional and locally screening (Davami et al., 2014; Aliowsati et al., 2013).

Human beings critically influence their environment, therefore, disorder in any element of a municipal system may cause a deficiency in the entire system (Meshkini et al., 2007). Although, various waste disposal approaches have significantly been developed worldwide, land-filling as yet is the most popularly applied procedure in third world countries (Yazdani et al., 2015b; Sumathi et al., 2008). In Iran, MSW landfilling is expanded day by day because of the rapid urban population growth and the changes in consumption patterns (Davami et al., 2014; Eskandari et al., 2012).

The aims of the present research were to show the unsuitability of the current landfill sites in studied area and therefore, addressing the locally preferred criteria for landfill site evaluation in the northern Iran, commonly referred to as the Caspian Landfill Criteria (CLC), using which the most suitable areas for landfill sites were formerly chosen. The final aim of this project was to apply the obtained results to illustrate the lack of suitable regions for MSW landfill.

The landfill sites are serious issues in the western part of Mazandaran due to the geographic conditions, including the proximity of forests and the sea, high groundwater levels and high tourists in holiday seasons, this region is in a more sensitive condition than the other parts of Mazandaran province (Yazdani et al., 2013). After the evaluation of landfill sites and showing the indications of land degradation, it is essential to restore these lands. Numerous researches have been carried out on land recovery after degradation using different methods which can be used in the future. For instance, there has been a report on restoration of mine dunes with fungi species (de Suza et al., 2011). Furthermore, in another study, limestone quarries has been resorted using three approaches; tree and shrub planting, no herb layer and hyseed (Gillardeli et al., 2013). (Pallavicini et al., 2014) have emphasised that environmental factors are very important for soil quality and development. It has also been shown that to forestation on degraded land (Haigh et al., 2013). Moreover, further researches have been carried out on forest restoration as well (Quinonero et al., 2016; Davies et al., 2010). Few studies have been conducted in Iran in the land restoration field (Sadeghi et al., 2015; Fallahzadeh et al., 2015). As to the sustainable municipal solid waste management, a wise plan in the western part of Mazandaran province should be prepared and performed.

\section{Materials and methods}

\section{Study area}

The studied area $\left(8761.5 \mathrm{~km}^{2}\right)$ is located in the western part of Mazandaran, Iran, which is situated in the southern coast of the Caspian Sea in northern edge of Iran. In a region consisting about 36.88 percent of the total area of this province about 20.87 percent of the population of Mazandaran province is concentrated (Iranian Statistic Centre, 2010). The 610120 inhabitants of this area generate about 181040 tons of waste per year. The elevation of the studied area varies from 27 meters below sea level to almost 4800 meters above sea level because of locating between the Alborz mountain range and the Caspian Sea. There are three distinct geomorphologic conditions with different weather conditions in the studies area; 
coastal plains and foothills with temperate and humid weather and mountains with cold weather (Mazandaran Governor, 2014).

In Iran, similarly to the other developing countries, landfilling has continued as customarily used procedure despite the increased attention to develop the MSW management (Yazdani et al., 2013; Eskandari et al., 2012; Sumathi et al., 2008). Landfilling sanitary municipal solid waste, just like any other engineering project, requires basic information and planning. The landfill in every area has important effects on environment.

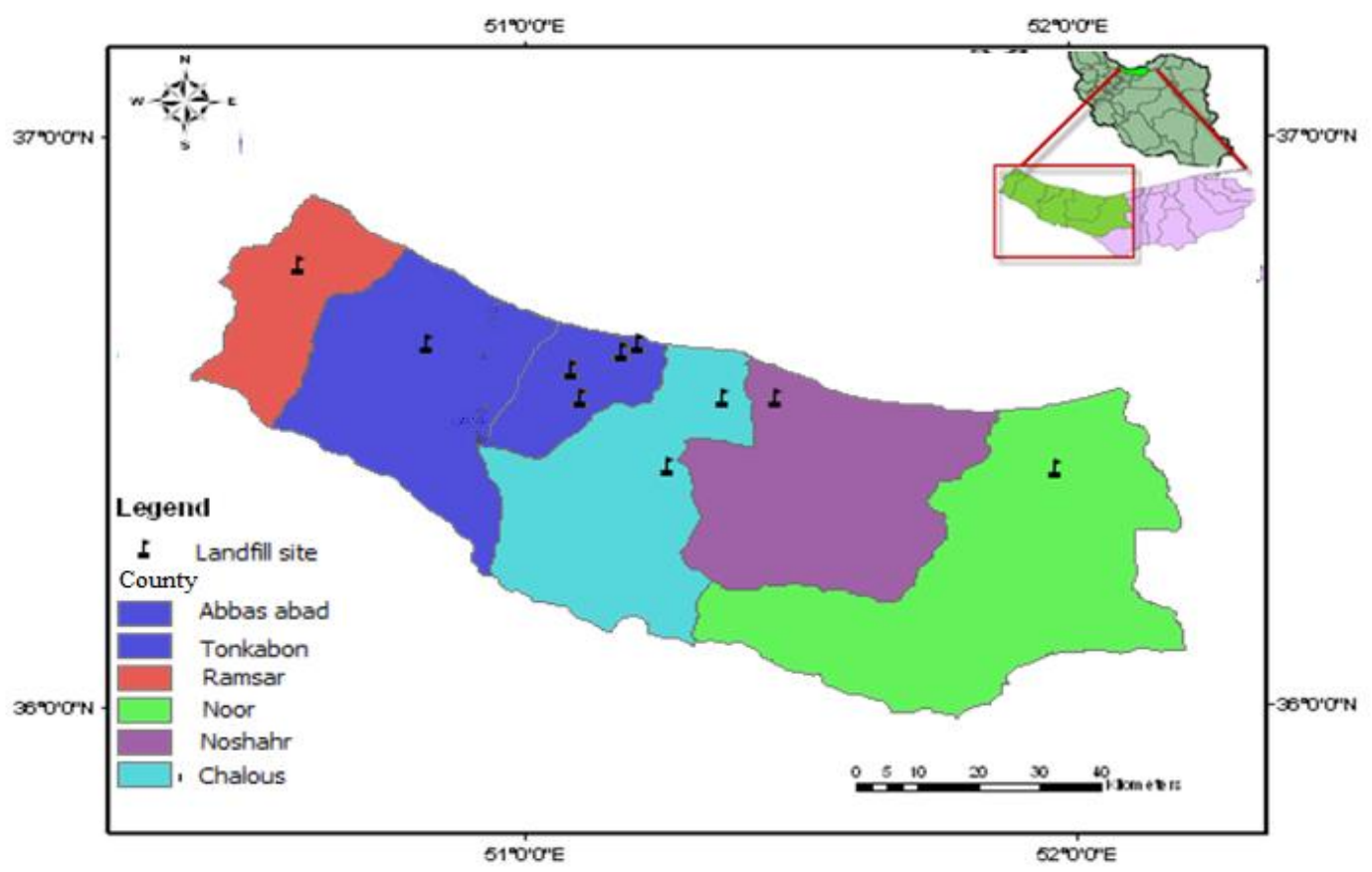

Figure 1. Landfill sites in the study area

\section{Evaluation of the landfill sites using seven standards}

The preliminary phase in the environmental impact assessment of landfill site is to know the sensitive parameters. Various methods have been introduced in literatures describing how to select a landfill site (Koshik et al., 2014; Alanbari et al., 2014; Elahi et al., 2014; Salimi et al., 2013; Eskandari et al., 2012; Moeinaddini et al., 2010; Shahabi et al., 2008; Sumathi et al., 2008; Hatzichristos and Giaoutzi, 2006; Heydarzadeh, 2001). The present study applied these methods to evaluate current municipal landfill sites situated in the studied area. In this study, 10 municipal waste landfills (Ramsar, Tonekabon, Abbas Abad, Kelardasht, Salmanshahr, Kelar Abad, Chalous, Marzan Abad, Noshahr, Noor) in 12 municipal districts were initially evaluated using the approved standards based upon the guidelines of British Columbia (BC), Environmental Protection Agency (EPA), Oleckno method, MPCA (Minnesota Pollution Control Agency), Regional Screening, Management and Programming Organization of Iran (MPO) and Iran Department of Environment (DOE). Each method and its criteria are mentioned and compared with each other in Table 1, however, the Oleckno index determination is mentioned separately in Table 2. In the Oleckno method, the annual average rainfall, soil type and soil depth are the three important 
factors which are considered to determine the rank of each landfill site. For this purpose the following equation was used (Monavari and Arbab, 2005; Salimi et al., 2013):

Oleckno Index Method Score = rainfall $(\mathrm{mm} /$ year $)+$ soil type + ground water table $(\mathrm{m})$

Table 1. Comparing the seven methods and their criteria

\begin{tabular}{|c|c|c|c|c|c|c|}
\hline $\begin{array}{l}\text { Criteria } \\
\text { methods }\end{array}$ & $\begin{array}{l}\text { Distance } \\
\text { to fault }\end{array}$ & Soil & $\begin{array}{l}\text { Groundwater } \\
\text { sources of } \\
\text { drinking } \\
\text { water }\end{array}$ & Distance to airports & $\begin{array}{l}\text { Flood plain, flood } \\
\text { basin }\end{array}$ & Land use \\
\hline $\begin{array}{l}\text { British } \\
\text { Colombia }\end{array}$ & & & $\begin{array}{l}\text { The distance } \\
\text { between the } \\
\text { discharged } \\
\text { MSW and the } \\
\text { nearest } \\
\text { residence, } \\
\text { water supply } \\
\text { well, water } \\
\text { supply intake, } \\
\text { is to be a } \\
\text { minimum of } \\
300 \text { meters. }\end{array}$ & $\begin{array}{l}\text { The distance } \\
\text { between an airport } \\
\text { utilized r by } \\
\text { commercial aircraft } \\
\text { and a landfill } \\
\text { containing food } \\
\text { wastes which may } \\
\text { attract birds is to be a } \\
\text { minimum of } 8.0 \\
\text { kilometers. }\end{array}$ & $\begin{array}{l}\text { Landfills proposed } \\
\text { for locations within } \\
\text { the } 200 \text { years } \\
\text { floodplain and the } \\
\text { associated } \\
\text { floodway are not to } \\
\text { be sited without } \\
\text { adequate protection } \\
\text { to prevent } \\
\text { washouts. }\end{array}$ & $\begin{array}{l}\text { The distance } \\
\text { between the } \\
\text { discharged MSW } \\
\text { and public park is } \\
\text { to be a minimum } \\
\text { of } 300 \text { meters. }\end{array}$ \\
\hline DOE & & & $\begin{array}{l}\text { In areas where } \\
\text { the water level } \\
\text { is high ,it } \\
\text { should be a2- } \\
\text { meter-deep } \\
\text { layer(made of } \\
\text { silt and } \\
\text { clay)and } \\
\text { maximum } \\
\text { permeability } \\
\text { millionths of a } \\
\text { centimeter per } \\
\text { second must be } \\
\text { provided }\end{array}$ & $\begin{array}{l}\text { Minimum of } 8 \\
\text { kilometers }\end{array}$ & & $\begin{array}{l}\text { Landfills should } \\
\text { not be in conflict } \\
\text { with Populated } \\
\text { areas or other land } \\
\text { uses distance to } \\
\text { farmland } \\
\text { 500metres, } \\
\text { distance to the } \\
\text { major cultural, } \\
\text { archaeological } \\
\text { and historical sites } \\
\text { must be suitable }\end{array}$ \\
\hline MPO & $\begin{array}{l}\text { Minimu } \\
\mathrm{m} \\
\text { distance } \\
\text { of } 300 \\
\text { meters }\end{array}$ & & $\begin{array}{l}\text { Minimum } \\
\text { distance of } 400 \\
\text { meters from } \\
\text { the municipal } \\
\text { water wells }\end{array}$ & 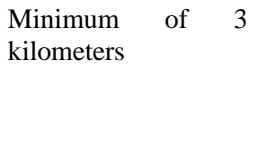 & & \\
\hline $\begin{array}{l}\text { MPCA } \\
\text { (Determin } \\
\text { ative } \\
\text { criteria) }\end{array}$ & & & & $\begin{array}{l}\text { Do not cumulate } \\
\text { birds in sensitive } \\
\text { area around airport }\end{array}$ & $\begin{array}{l}\text { Distance from area } \\
\text { with } 100 \text { years } \\
\text { retention } \\
\text { flood }\end{array}$ & \\
\hline EPA & $\begin{array}{l}\text { The } \\
\text { distance } \\
\text { from } \\
\text { faults } \\
\text { must be } \\
\text { at least } \\
60 \text { meters }\end{array}$ & $\begin{array}{l}\text { Distance } \\
\text { to areas } \\
\text { with } \\
\text { unstable } \\
\text { soil }\end{array}$ & & $\begin{array}{l}\text { Distance within } 3048 \\
\text { meters of runway } \\
\text { airports turbojet } \\
\text { aircraft, the distance } \\
\text { of } 1524 \mathrm{~m} \text { from the } \\
\text { runway airports } \\
\text { piston aircraft }\end{array}$ & $\begin{array}{l}\text { Distance from area } \\
\text { with } 100 \text { retention } \\
\text { period flood }\end{array}$ & \\
\hline
\end{tabular}




\begin{tabular}{|c|c|c|c|c|c|}
\hline $\begin{array}{l}\text { Regional } \\
\text { screening }\end{array}$ & $\begin{array}{l}\text { The } \\
\text { distance } \\
\text { from } \\
\text { faults } \\
\text { must be } \\
\text { at least } \\
61 \text { meters }\end{array}$ & $\begin{array}{l}\text { The } \\
\text { areas } \\
\text { with } \\
\text { shortage } \\
\text { supply } \\
\text { of heavy } \\
\text { clay and } \\
\text { fine } \\
\text { grained } \\
\text { soil for } \\
\text { using } \\
\text { coating } \\
\text { layers } \\
\text { are not } \\
\text { suitable } \\
\text { for } \\
\text { municip } \\
\text { al solid } \\
\text { waste } \\
\text { landfill } \\
\text { sitting. }\end{array}$ & $\begin{array}{l}\text { Regions with } \\
\text { high } \\
\text { underground } \\
\text { water levels } \\
\text { are not } \\
\text { compatible for } \\
\text { MSW sites, if } \\
\text { the hydraulic } \\
\text { trap method is } \\
\text { used. At least } \\
300 \text { meters } \\
\text { distance from } \\
\text { water wells }\end{array}$ & $\begin{array}{lll}\text { At least } 3 & \mathrm{~km} \\
\text { distance from } & \text { the } \\
\text { airport. } & & \end{array}$ & $\begin{array}{l}\text { At least distance } \\
\text { of } 150 \mathrm{~m} \text { from, } \\
\text { commercial, } \\
\text { educational and } \\
\text { residential centers } \\
\text { and at least } 80 \mathrm{~m} \\
\text { from industrial } \\
\text { applications. The } \\
\text { agricultural land } \\
\text { use can be } \\
\text { suitable for solid } \\
\text { waste landfill sites }\end{array}$ \\
\hline
\end{tabular}

Continue Table 1.

\begin{tabular}{|c|c|c|c|c|c|}
\hline Criteria & $\begin{array}{ll}\begin{array}{l}\text { Surface } \\
\text { (lake, }\end{array} & \begin{array}{l}\text { water } \\
\text { river, }\end{array} \\
\text { lagoon) } & \\
\end{array}$ & Geology & $\begin{array}{l}\text { Distance to } \\
\text { residential areas }\end{array}$ & $\begin{array}{l}\text { Distance to } \\
\text { road }\end{array}$ & Preserve and bird habitat \\
\hline BC & $\begin{array}{l}\text { The distance } \\
\text { between the } \\
\text { discharged MSW } \\
\text { and the nearest } \\
\text { surface water is to } \\
\text { be a minimum of } \\
100 \text { meters. }\end{array}$ & $\begin{array}{l}\text { Landfills are not to } \\
\text { be located within } \\
100 \text { meters of an } \\
\text { unstable area }\end{array}$ & $\begin{array}{l}\text { The distance } \\
\text { between the } \\
\text { discharged MSW } \\
\text { and the nearest } \\
\text { residence, hotel, } \\
\text { restaurant, food } \\
\text { processing facility, } \\
\text { school, church or } \\
\text { public park is to be } \\
\text { a minimum of } 300 \\
\text { meters. }\end{array}$ & & $\begin{array}{l}\text { The buffer zone between the } \\
\text { discharged MSW and the } \\
\text { property boundary should be } \\
\text { at least } 50 \text { meters of which } \\
\text { the } 15 \text { meters closest to the } \\
\text { property boundary must be } \\
\text { reserved for natural or } \\
\text { landscaped screening (berms } \\
\text { or vegetative screens ) }\end{array}$ \\
\hline DOE & $\begin{array}{l}\text { Landfills should not } \\
\text { be located in the } \\
\text { wetlands and unique } \\
\text { habitats } \\
\text { Minimum distance } \\
\text { of } 2000 \text { meters to } \\
\text { surface waters }\end{array}$ & $\begin{array}{l}\text { Not to be Placed } \\
\text { on faults, } \\
\text { underground } \\
\text { mines, subsidence } \\
\text { and collapse of } \\
\text { cavities }\end{array}$ & $\begin{array}{l}\text { Distance of } 10-15 \\
\text { kilometers from the } \\
\text { city }\end{array}$ & $\begin{array}{l}\text { Distance of } \\
3-5 \\
\text { kilometers to } \\
\text { main road }\end{array}$ & \\
\hline MPO & $\begin{array}{l}\text { Wetlands should not } \\
\text { be selected as the } \\
\text { burial place } \\
\text {,landfills must be } \\
\text { away from lakes } \\
\text { ponds more } \\
\text { than300meters.Mini } \\
\text { mum distance of } \\
100 \text { meters to rivers }\end{array}$ & & & $\begin{array}{l}\text { Minimum } \\
\text { distance of } \\
300 \text { meters }\end{array}$ & \\
\hline
\end{tabular}




\begin{tabular}{|c|c|c|c|}
\hline MPCA & $\begin{array}{lr}\text { Minimum } & 305 \\
\text { meters distance } \\
\text { from any lake or } \\
\text { pool, } \\
\text { Minimum92meters } \\
\text { distance from any } \\
\text { river or channel, } \\
\text { Avoiding from } \\
\text { wetlands }\end{array}$ & $\begin{array}{l}\text { Distance from area } \\
\text { with limestone } \\
\text { caves }\end{array}$ & \\
\hline EPA & $\begin{array}{l}\text { Landfills should not } \\
\text { be located in the } \\
\text { wetlands }\end{array}$ & $\begin{array}{l}\text { Distance to high } \\
\text { seismic areas, } \\
\text { (displacement of } \\
\text { rocks and karst } \\
\text { areas) }\end{array}$ & \\
\hline $\begin{array}{c}\text { Regional } \\
\text { screening }\end{array}$ & $\begin{array}{l}\text { The MSW landfill } \\
\text { sites should not be } \\
\text { sited near the } \\
\text { surface water } \\
\text { (minimum distance } \\
\text { of } 61 \mathrm{~m} \text { should be } \\
\text { observed). }\end{array}$ & $\begin{array}{l}\text { The regions with } \\
\text { slide risk potential } \\
\text { and sensitive clays } \\
\text { are not suitable for } \\
\text { landfill sites. The } \\
\text { regions with high } \\
\text { sensitive soils such } \\
\text { as limestone and } \\
\text { fragile soils are not } \\
\text { suitable for landfill } \\
\text { sites. The MSW } \\
\text { landfill site should } \\
\text { not be sited in the } \\
\text { ravines }\end{array}$ & $\begin{array}{l}\text { A proper } \\
\text { distance } \\
\text { from the } \\
\text { main road } \\
\text { should be } \\
\text { considered. ( } \\
\text { Less than } \\
\text { one } \\
\text { kilometer is } \\
\text { ideal)(econo } \\
\text { mic) }\end{array}$ \\
\hline
\end{tabular}

Table 2. The indices of rank determining in Oleckno method

\begin{tabular}{|c|c|c|c|c|}
\hline $\begin{array}{l}\text { The annual } \\
\text { average rainfall } \\
(\mathrm{mm} / \text { year) }\end{array}$ & $\begin{array}{l}\text { Less than } 250 \\
\text { (mm/year) }\end{array}$ & $\begin{array}{c}255-760 \\
(\mathrm{~mm} / \text { year })\end{array}$ & $\begin{array}{c}\text { 765-1780 } \\
(\mathrm{mm} / \text { year })\end{array}$ & \\
\hline Score & 21 & 7 & 6 & \\
\hline \multirow[t]{2}{*}{ Soil type } & $\begin{array}{l}\text { Clay silt or } \\
\text { clay and sand }\end{array}$ & Silt and soft sand & Mud & Gravel and cobble \\
\hline & 12 & 5 & 4 & 0 \\
\hline Soil depth(m) & $1.5-3$ & $3-6$ & $6-9$ & $9<$ \\
\hline Score & 3 & 7 & 9 & 9 \\
\hline Oleckno rank & Good & Acceptable & Unacceptable & \\
\hline Score & $24-42$ & $21-23$ & $>20$ & \\
\hline
\end{tabular}

The present study consisted of two phases; first phase included determining the characteristics of the 10 landfill sites by reviewing the library data, previously published literatures and using the ArcGIS software maps (version 10.2). The second phase is to address the locally preferred criteria for landfill site evaluation in the northern Iran for Caspian Landfill Criteria (CLC) model.

Most of the information was obtained from the Mazandaran Management and Planning Office of the Governor with a scale of 1:100000. The hydrology and hydrogeology maps (surface and groundwater maps) with a scale of 1:250000 were 
obtained from the Geographic Information Centre of the Mazandaran Regional Water Organization. By locating the GPS coordinates of the available landfill sites in field view and entering them as latitude and longitude in the GIS software database the landfill site map layer was prepared. The gathered data were then converted into a point data. Thematic maps, characterizing the affecting factors, were generated for landfill sites evaluation (Yazdani et al., 2013). The map layers of the evaluation criteria in the study area are shown in Fig. 2. The steps of the first phase of the present research are illustrated in Fig. 3. All the mentioned steps are considered in each of the seven evaluation methods for total research area.

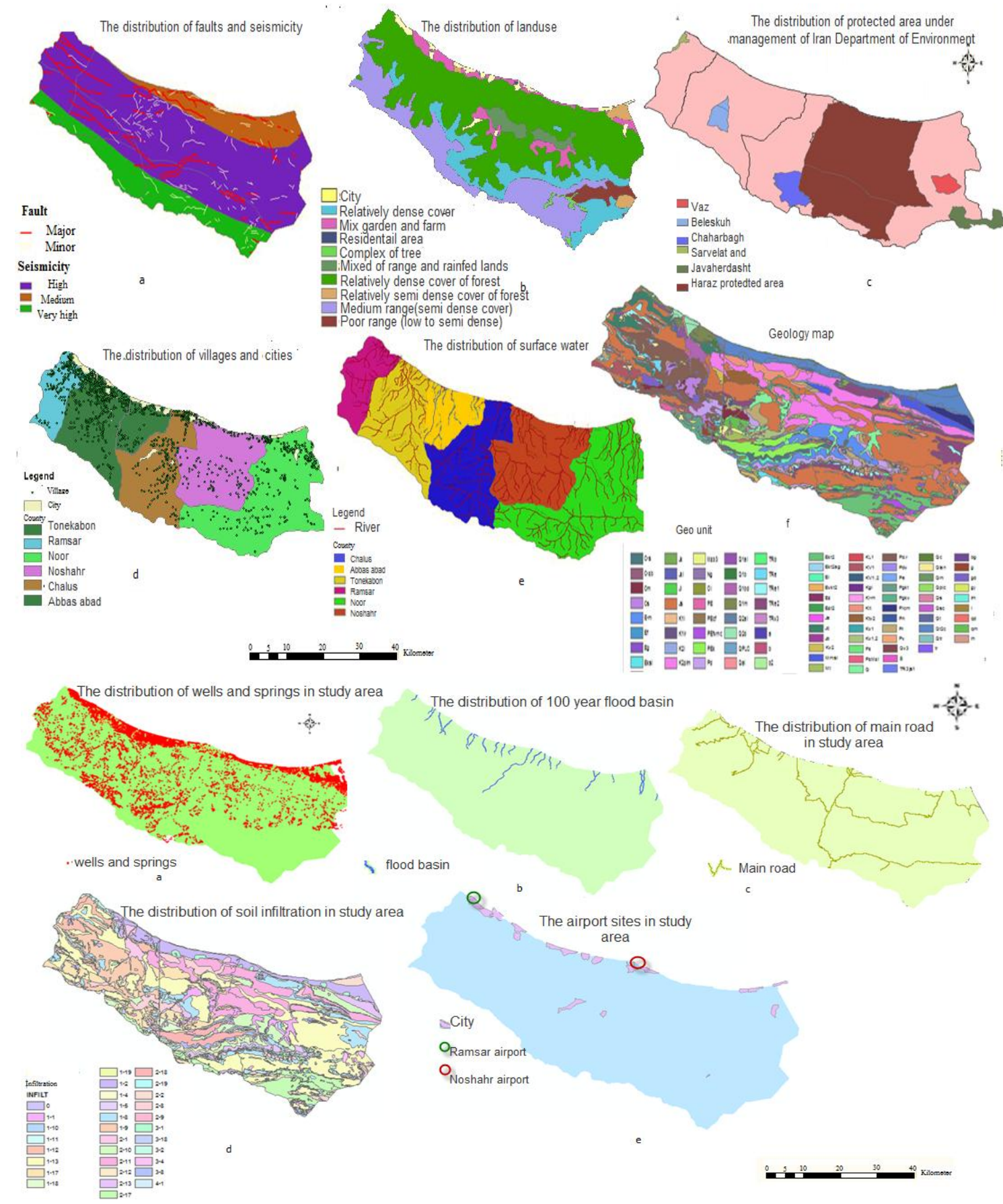

Figure 2. Criteria maps in the study area 


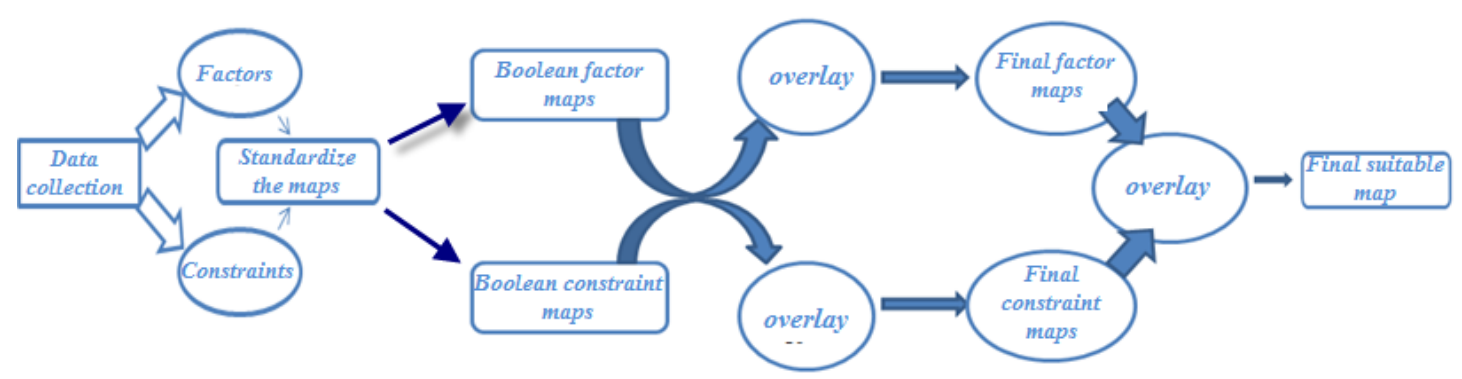

Figure 3. The research steps in first phase (Yazdani et al., 2015a)

There were two types of map in first phase of the study; factors (such as faults map and landuse), constraints (such as distance to spring, distance to road, distance to rivers and distance to protected areas). Since there are some regulations applying these seven methods to evaluate landfill sites, Boolean logic was used to standardize the constraint and factor of the map layers. Therefore, all the areas that are impermissible for landfill site sitting according to the 7 guidelines and their principals (constraints) as well as whole areas that fall inside the restricted area (buffers) which landfill site development is prohibited in ArcGIS software with the reclassified module were determined. In map layers the value of the restricted area (unsuitable area) was 0 and that of the other area was 1 (suitable area) (Yazdani et al., 2015a). Different criteria map layers were prepared according to the extant standards which are mentioned in Table 1. Buffer maps using the buffer option in ArcGIS were prepared for various criteria. The areas falling inside the buffer areas are unsuitable for municipal solid waste landfill site sitting.

The GIS-based constraint mapping technique was then used to evaluate the suitability of each existing landfill site in studied area considering all the mentioned criteria in each method. The results are shown in Table 3.

The overlaying of Boolean factor maps is shown in Fig. 4 and Fig. 5 shows the overlaying of Boolean constraint maps in Iran Department of Environment (DOE) method. The final suitable map according to DOE method is shown in Fig. 6.

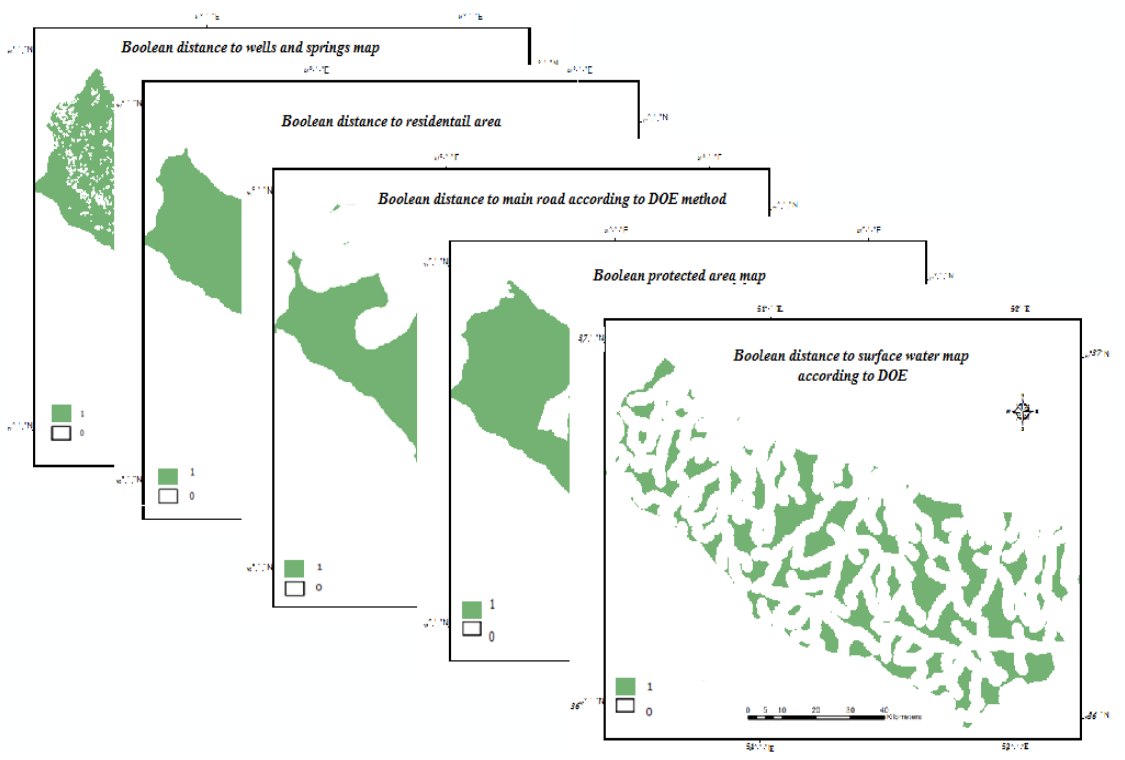

Figure 4. Overlay of Boolean constraint maps to achieve the final suitable map in DOE method 


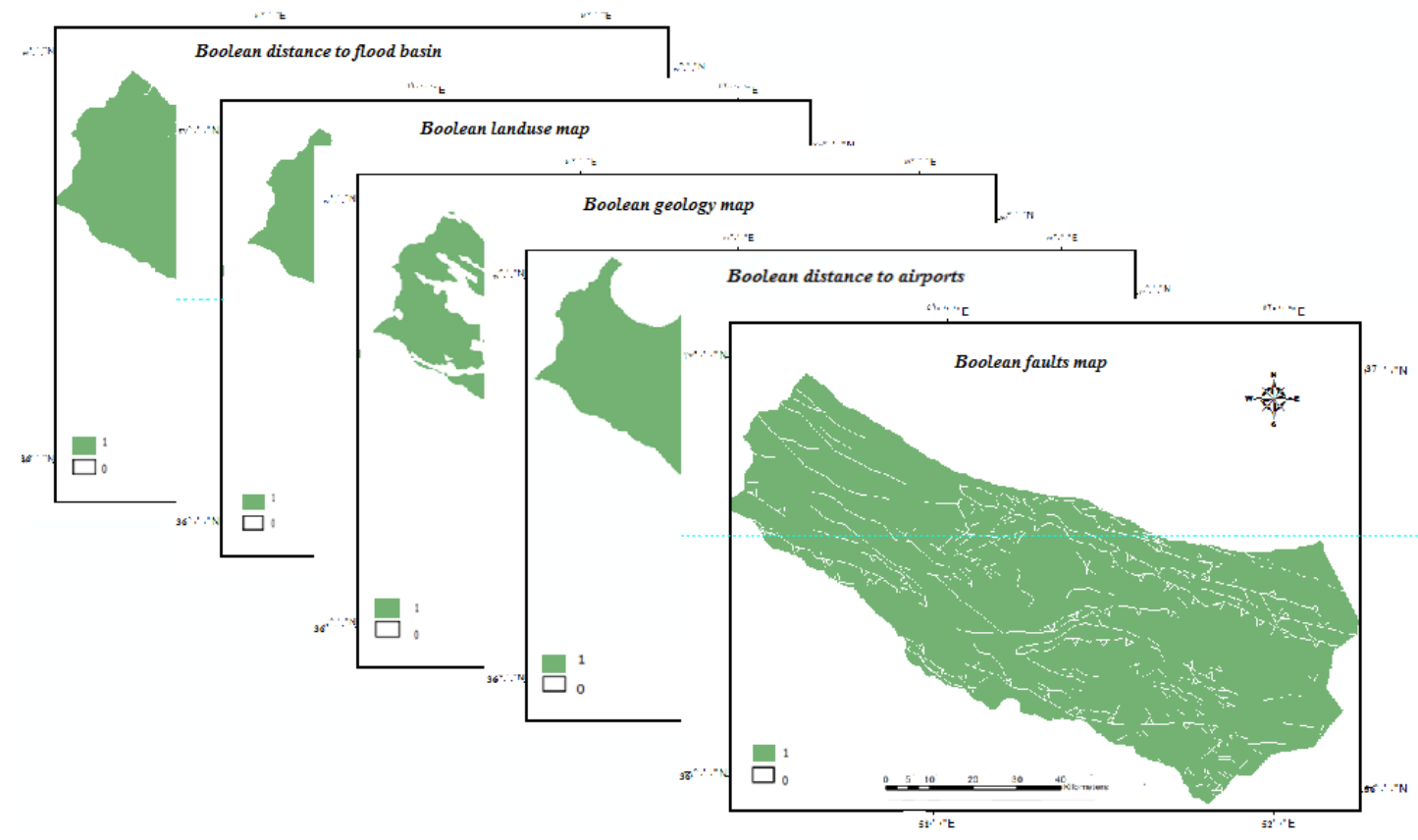

Figure 5. Overlay of Boolean factor maps to achieve the final suitable map in DOE method

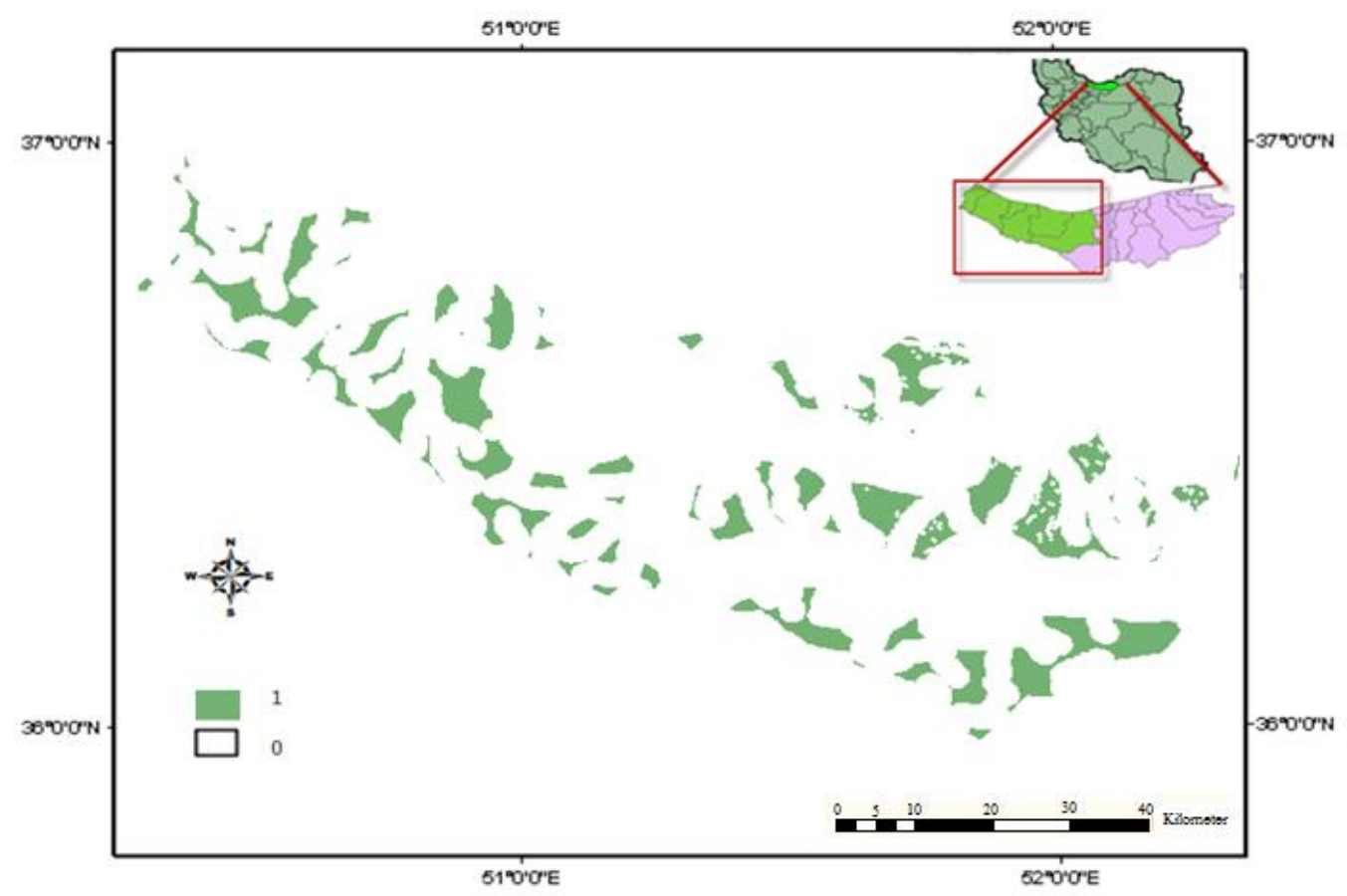

Figure 6. Final suitable map according to DOE method after overlaying Boolean constraint maps and Boolean factor maps

\section{Evaluation criteria for Caspian Landfill Criteria (CLC) model}

The second phase of the study consisted of four main stages to select and evaluate landfill site based on the Caspian Landfill Criteria (CLC) model; choosing evaluation criteria using Delphi method, standardizing map layers with Boolean logic and fuzzy 
functions, application of Analytical Hierarchy Process (AHP) method to identify the importance of the selected criteria and finally combining the information gathered from various criteria to combine a single evaluation index with Multi Criteria Evaluation (MCE).

Table 3. The suitability of landfill sites with 7 methods in first phase

\begin{tabular}{|c|c|c|c|c|c|c|c|}
\hline $\begin{array}{c}\text { Landfill site } \\
\text { name }\end{array}$ & $\begin{array}{l}\text { Regional } \\
\text { screening } \\
\text { suitability }\end{array}$ & $\begin{array}{c}\text { BC } \\
\text { suitability }\end{array}$ & $\begin{array}{c}\text { EPA } \\
\text { suitability }\end{array}$ & $\begin{array}{c}\text { MPO } \\
\text { suitability }\end{array}$ & $\begin{array}{c}\text { DOE } \\
\text { suitability }\end{array}$ & $\begin{array}{c}\text { MPCA } \\
\text { suitability }\end{array}$ & $\begin{array}{c}\text { Oleckno } \\
\text { suitability }\end{array}$ \\
\hline Ramsar & Unsuitable & Suitable & Unsuitable & Unsuitable & Unsuitable & Suitable & Suitable \\
\hline Tonekabon & Unsuitable & Suitable & Unsuitable & Unsuitable & Unsuitable & Suitable & Suitable \\
\hline Abbas abad & Unsuitable & Suitable & Unsuitable & Unsuitable & Unsuitable & Suitable & Suitable \\
\hline Kelardasht & Unsuitable & Suitable & Unsuitable & Unsuitable & Unsuitable & Suitable & Suitable \\
\hline Salmanshahr & Unsuitable & Unsuitable & Unsuitable & Unsuitable & Unsuitable & Unsuitable & Suitable \\
\hline Kelar abad & Unsuitable & Unsuitable & Suitable & Unsuitable & Unsuitable & Suitable & Unsuitable \\
\hline Chalous & Unsuitable & Suitable & Unsuitable & Unsuitable & Unsuitable & Suitable & Suitable \\
\hline Marzan abad & Unsuitable & Suitable & Unsuitable & Suitable & Unsuitable & Suitable & Suitable \\
\hline Noshahr & Unsuitable & Unsuitable & Suitable & Unsuitable & Unsuitable & Unsuitable & Unsuitable \\
\hline Noor & Suitable & Suitable & Suitable & Unsuitable & Unsuitable & Suitable & Unsuitable \\
\hline $\begin{array}{l}\text { Suitability } \\
\text { percent of the } \\
\text { total study } \\
\text { area }\end{array}$ & 58.17 & 62.38 & 77.9 & 48.5 & 20 & 95.32 & 38.9 \\
\hline
\end{tabular}

\section{Choosing the evaluation criteria}

At first, the Delphi technique was used to identify the suitable criteria. This method is an effective tool to achieve a well-thought-through consensus among experts. Delphi technique has been applied in MSW landfill site sitting in the past (Sumathi et al., 2008; Hatzichristos et al., 2006; Koshik et al., 2014). Therefore, the findings of twenty experts in the field, with the most relevant experience, have been included to determine which factors should be considered for alternative ranking. This was accomplished using questionnaire form. A list of criteria based on the 7 mentioned guidelines, as well as a review of the scientific periodicals on previously works was conducted in the questionnaire form. The experts who were familiar with the studied area and participated in the study were requested to supply a list of the preferred evaluation criteria for landfill site selection and evaluation. To data, 18 important criteria have been determined to evaluate landfill sites, and thus, were prepared as input map layers.

\section{Standardizing map layers}

Considering the fact that to measure the criteria a variety of scales are used, therefore, it is necessary that the values present in layers of different criteria could be changed into proportional and comparable units. The map layers were standardized in a GIS environment using fuzzy and Boolean logic functions. Boolean logic was used to standardize the constraint map layers. Therefore, in ArcGIS software with the reclassified module was determined. In map layers the value of the restricted area (unsuitable area) was 0 and that of the other area was 1 (suitable area) (Yazdani et al., 2015a). To standardize the factor map layers the criteria-related fuzzy approach was used. To make fuzzy factor maps the threshold should be determined for the values of the criteria, the type and shape of the membership function which are shown in Table 4 are required. 
The maps were standardized in the 0-255 range for each criterion with 0 as the least and 255 as the maximum suitability range. The linear function which is provided using IDRISI software is applied in the present study.

Due to its high capabilities, IDRISI software was applied to calculate the weights of the criteria, to standardize the criteria by fuzzy functions and also to merge the criteria by MCE model. Therefore, IDRISI software is a suitable option for decision-making using spatial information (Moeinaddini et al., 2010). To quantify the fuzzy diagrams (membership functions), linear scale conversion method was used based on minimum and maximum values as scaling points. In monotonically increasing functions, the linear scale transformation method was used as shown in equation (1) (Eastman, 2012).

$$
\begin{gathered}
\mathrm{X}_{\mathrm{i}}=1-\frac{(\mathrm{Ri}-\mathrm{Rmin})}{\left(\mathrm{R}_{\max }-\mathrm{R}_{\min }\right)} * \text { standardized_range } \\
\mathrm{X}_{\mathrm{i}}=\frac{(\mathrm{Ri}-\mathrm{Rmin})}{\left(\mathrm{R}_{\max }-\mathrm{R}_{\min }\right)} * \text { standardized_range }
\end{gathered}
$$

where:

$\mathrm{X}_{\mathrm{i}}$ is pixel value after standardization,

$\mathrm{R}_{\mathrm{i}}$ is pixel value before standardization,

$\mathrm{R}$ min is minimum point in factor,

$\mathrm{R}$ max is maximum point in factor,

Standardized_range is range standardization (on a scale of 255 bytes).

In monotonically decreasing linear functions, linear scale transformation method was sued based on equation (2). In symmetric (trapezoidal) functions, a combination of equations (1) and (2) was used. All these steps were carried out in the ArcGIS and IDRISI software with Con conditional statement. In the case of discontinuous functions, such as land use and geological factors, the fuzzy values associated with each class were determined using equation (1).

Table 4. Factors used to form the landfill site sitting suitability map, with indications on their endpoints (the $2^{\text {nd }}$ one shows to the highest suitability value and the 1st endpoint to the lowest) and their comparative weight, M.I (Monotonically increasing), M.D

\begin{tabular}{|c|c|c|c|c|}
\hline $\begin{array}{c}\text { Criteria } \\
\text { [unit of measurement] }\end{array}$ & End point 1 & End point 2 & Weight & $\begin{array}{l}\text { Fuzzy } \\
\text { function }\end{array}$ \\
\hline $\begin{array}{l}\text { Distance from population } \\
\text { center }[\mathrm{m}]\end{array}$ & $\begin{array}{l}5000 \\
9000\end{array}$ & 7500 & 0.109 & $\mathrm{~S}$ \\
\hline $\begin{array}{c}\text { Soil depth } \\
\text { [qualitative classes] }\end{array}$ & 1 & 5 & 0.034 & M.I \\
\hline Distance from sea[m] & 3000 & 5000 & 0.082 & M.I \\
\hline Distance from faults [m] & 1000 & 3000 & 0.016 & M.I \\
\hline $\begin{array}{c}\text { Bedrock material } \\
\text { [qualitative classes]* }\end{array}$ & 1 & 5 & 0.015 & M.I \\
\hline Soil infiltration & 1 & 5 & 0.054 & M.I \\
\hline $\begin{array}{c}\text { Distance from industrial } \\
\text { center }[\mathrm{m}]\end{array}$ & 300 & 600 & 0.041 & M.I \\
\hline
\end{tabular}
(Monotonically decreasing) and S (symmetric) 


\begin{tabular}{|c|c|c|c|c|}
\hline $\begin{array}{l}\text { Distance from surface water } \\
{[[\mathrm{m}]}\end{array}$ & 3000 & 4500 & 0.112 & M.I \\
\hline Distance from airport [m] & 3000 & & 0.040 & M.I \\
\hline Distance from main road $[\mathrm{m}]$ & $\begin{array}{c}3000 \\
10000\end{array}$ & 5000 & 0.040 & S \\
\hline $\begin{array}{l}\text { Distance from wetland, lake } \\
{[\mathrm{m}]}\end{array}$ & 500 & 1000 & 0.059 & M.I \\
\hline $\begin{array}{c}\text { Distance from sensitive } \\
\text { ecosystem [m] }\end{array}$ & 500 & 1000 & 0.029 & M.I \\
\hline Slope [percent] & 40 & 20 & 0.015 & M.D \\
\hline $\begin{array}{l}\text { Land use [qualitative } \\
\text { classes]* }\end{array}$ & 1 & 5 & 0.029 & M.I \\
\hline $\begin{array}{l}\text { Distance from flood basin } \\
{[\mathrm{m}]}\end{array}$ & 2000 & 5000 & 0.061 & M.I \\
\hline Soil texture [qualitative]* & 1 & 5 & 0.049 & M.I \\
\hline Ground water table $[\mathrm{m}]$ & 5 & 10 & 0.049 & M.I \\
\hline $\begin{array}{l}\text { Distance from underground } \\
\text { water sources }[\mathrm{m}]\end{array}$ & 500 & 1000 & 0.109 & M.I \\
\hline
\end{tabular}

* are mentioned in Table 5.

\section{Application of AHP method}

After the GIS database for landfill site sitting and the thematic map layers for each criterion were prepared and their importance were identified, a relative classification was carried out for each factor based on the relative influence of each criterion. In this study, analytical hierarchy process (AHP) was applied for pair-wise comparison to create comparative weights. In the AHP, the first step is the decomposition of a difficult complex decision into the easier decision subject to form a hierarchical model. In each hierarchical model, the upside level is the final goal (in this study the goal is landfill site evaluation). In analysis step, simultaneous pair wise comparisons between each both criteria and their relative values was carried out using the Expert Choice software for a simple classification. The comparison matrix was developed for eighteen criteria. The criteria weights are shown in Table 4.

\section{Combining criteria using MCE (Multi Criteria Evaluation)}

Multi criteria evaluation is mainly used to incorporate the different criteria to form a single evaluation index (Voogd, 1983). After standardization of criteria maps (factors and constraints) and determining the weights factors, the next step was to perform multi-criteria evaluation process. The Boolean intersection logic, AND logic or the multiplied or logic function according to equation (3) were used to integrate layers of constraints and provide the final layer. All criteria weights were considered equal (Eastmen, 2012).

$$
\mathrm{C}=\Pi c \mathrm{j}
$$


where $\mathrm{C}$ is final constraints, $\Pi$ is multiplied index, $\mathrm{cj}$ is constraints criterion $\mathrm{j}$ score.

Considering the fact that, the Weighted Linear Combination (WLC) is one of the best and useful methods of multi-criteria decision making (Heydarzadeh 2001), was used throughout this study. In order to perform the assessment process using this method in the present study, each factor (criterion) was multiplied by its corresponding weight according to the equation (4).

The unsuitable areas were omitted by summing the gathered results and multiplying the constraints. Consequently, the suitable area(s) for landfill sitting was obtained.

$$
\mathrm{S}=\Sigma \mathrm{WiXi \Pi cj}
$$

where $\mathrm{S}$ is suitability, Wi is weight of factor $\mathrm{i}, \mathrm{Xi}$ is fuzzy value of factor $\mathrm{i}, \Pi$ is multiplied index, $\mathrm{Cjis}$ is constraints criterion $\mathrm{j}$ score.

WLC approach was applied in IDRISI software according to equation (2). After generating a raster map in ArcGIS software (this map is based on the pixel level) using the "Re class" command, (Re class), the final plotted map was divided to 5 sections from 0 as the minimum to 250 as the maximum suitability rate.

\section{Results}

After reviewing each waste deposit site, considering all the criteria in every 7 methods applied in the present study, the incoherence in suitability was apparent in first phase. For example, some sites were suitable using one method, but unsuitable using another. The suitability report of the studied landfill sites is shown in Table 3. Thus, presenting unique locally parameters suited to particular ecological conditions, seems necessary for evaluating all landfill sites. To achieve a comprehensive and applicable evaluation, the criteria should be defined in accordance with the locally condition of the studies area. The review of all existing methods has shown that none of them have considered the distance from sea, which is critically important for the entire region. Considering the importance of high priority data layers in MCE, the weighting of these layers and the fact that each of these criteria and their importance changes in accordance with the special environmental conditions, it is necessary to localize the criteria for different environmental zones. Therefore, 18 factors were used for alternative ranking (shown in Table 4) in CLC model. The map layers of each of these 18 factors are essential to be thought out. Consequently, the eighteen essential evaluation criteria including their regulations and constraints were prepared based on the prior inspections, present regulations, point of view and questionnaires answered by twenty specialists familiar with the field of study and also familiar to studied area (the Delphi method).

Based on the availability of the data, these 18 important criteria were modified in order to evaluate the landfill sites, as input map layers. In the present study, a GIS/MCE integrated method has been used for the data analysis. Furthermore, the results were compared and the accuracy was checked using an AHP/Fuzzy integrated method. Table 4 indicates that the fuzzy approach was applied for standardization and the weights of each criterion (preferred value). The description of qualitative criteria is indicated in Table 5. Five standard maps out of eighteen are showed as samples in Fig. 7. The standardized maps were divided into 5 classes in the 0-255 range for each criterion with 0 (unsuitable) to 255 (most suitable areas). In this study, a multi-criteria evaluation approach integrated with Arc GIS overlay analysis was used to choose the most 
preferable landfill site in studied area. The suitable regions were recognized for landfilling considering the final map layer. In executing the CLC model, the important of the weights and the preferred value of each of the criterion are critical.

In the present study, parameters and their prioritization includes distance to river, distance to population centres, distance to springs and wells, distance to sea, flood plains, distance to lakes and lagoons, the rate of soil infiltration, soil texture and underground level, distance from the airports and main roads, the depth of soil, distance from sensitive habitats and land use, distance from fault and, the least important one, the stone material of context and slope.

The results of this study have been achieved using fuzzy multi-criteria decision making and analytic hierarchy process, which are similar to that used in researches on locating and evaluating landfill sites. This integrated method can be used in areas similar to those in this study or, to be more general, in the coastal regions of the Caspian Sea.

Table 5. Qualitative criteria description

\begin{tabular}{|c|c|c|c|c|c|}
\hline Criteria & 1 & 2 & 3 & 4 & 5 \\
\hline $\begin{array}{l}\text { Suitability } \\
\text { range }\end{array}$ & $\begin{array}{c}\text { Very } \\
\text { unsuitable }\end{array}$ & Unsuitable & Low suitability & Suitable & Very suitable \\
\hline $\begin{array}{l}\text { Bed rock } \\
\text { material }\end{array}$ & $\begin{array}{l}\text { Permeable } \\
\text { flood basin } \\
\text { floor }\end{array}$ & $\begin{array}{l}\text { Sand, stone, } \\
\text { limestone, dolomite, } \\
\text { deposits range, } \\
\text { conglomerates, } \\
\text { alluvial fans, alluvial } \\
\text { present covenant }\end{array}$ & $\begin{array}{l}\text { Igneous and } \\
\text { metamorphic } \\
\text { rocks with low } \\
\text { breakage and silt }\end{array}$ & $\begin{array}{l}\text { Schist, } \\
\text { clay, tuff, } \\
\text { evaporated } \\
\text { rock, } \\
\text { clay and } \\
\text { mud, fine } \\
\text { loss }\end{array}$ & $\begin{array}{l}\text { Shale, marl } \\
\text { and clay }\end{array}$ \\
\hline $\begin{array}{l}\text { Soil type } \\
\text { (depth and } \\
\text { texture) }\end{array}$ & $\begin{array}{l}\text { Shallow to } \\
\text { moderately } \\
\text { deep soils } \\
\text { with } \\
\text { limestone, } \\
\text { or with } \\
\text { gravel } \\
\text { bearing }\end{array}$ & $\begin{array}{l}\text { Shallow to } \\
\text { moderately deep } \\
\text { soils, medium to } \\
\text { heavy pebble texture } \\
\text { on the rocks, } \\
\text { moderately deep to } \\
\text { deep loamy to } \\
\text { gravelly soil }\end{array}$ & $\begin{array}{l}\text { Deep heavy } \\
\text { texture soils in } \\
\text { some areas with } \\
\text { limestone floor } \\
\text { concentration }\end{array}$ & $\begin{array}{l}\text { Deep soil } \\
\text { with } \\
\text { moderate } \\
\text { to heavy } \\
\text { texture }\end{array}$ & $\begin{array}{l}\text { Deep soil } \\
\text { with heavy } \\
\text { texture, } \\
\text { moderately } \\
\text { deep to deep } \\
\text { soils }\end{array}$ \\
\hline Land use & $\begin{array}{l}\text { Forest, } \\
\text { dense } \\
\text { range, } \\
\text { populated } \\
\text { area, river } \\
\text { floor }\end{array}$ & $\begin{array}{l}\text { Very low densities of } \\
\text { forest, agricultural } \\
\text { lands, Gardens }\end{array}$ & $\begin{array}{l}\text { Semi dense range, } \\
\text { agricultural land, } \\
\text { incorporating } \\
\text { gardens }\end{array}$ & $\begin{array}{l}\text { Poor range, } \\
\text { low } \\
\text { density } \\
\text { other land }\end{array}$ & $\begin{array}{l}\text { Land without } \\
\text { vegetation, } \\
\text { rocky } \\
\text { protrusions }\end{array}$ \\
\hline Infiltration & Very high & High & Medium & Low & Very low \\
\hline
\end{tabular}




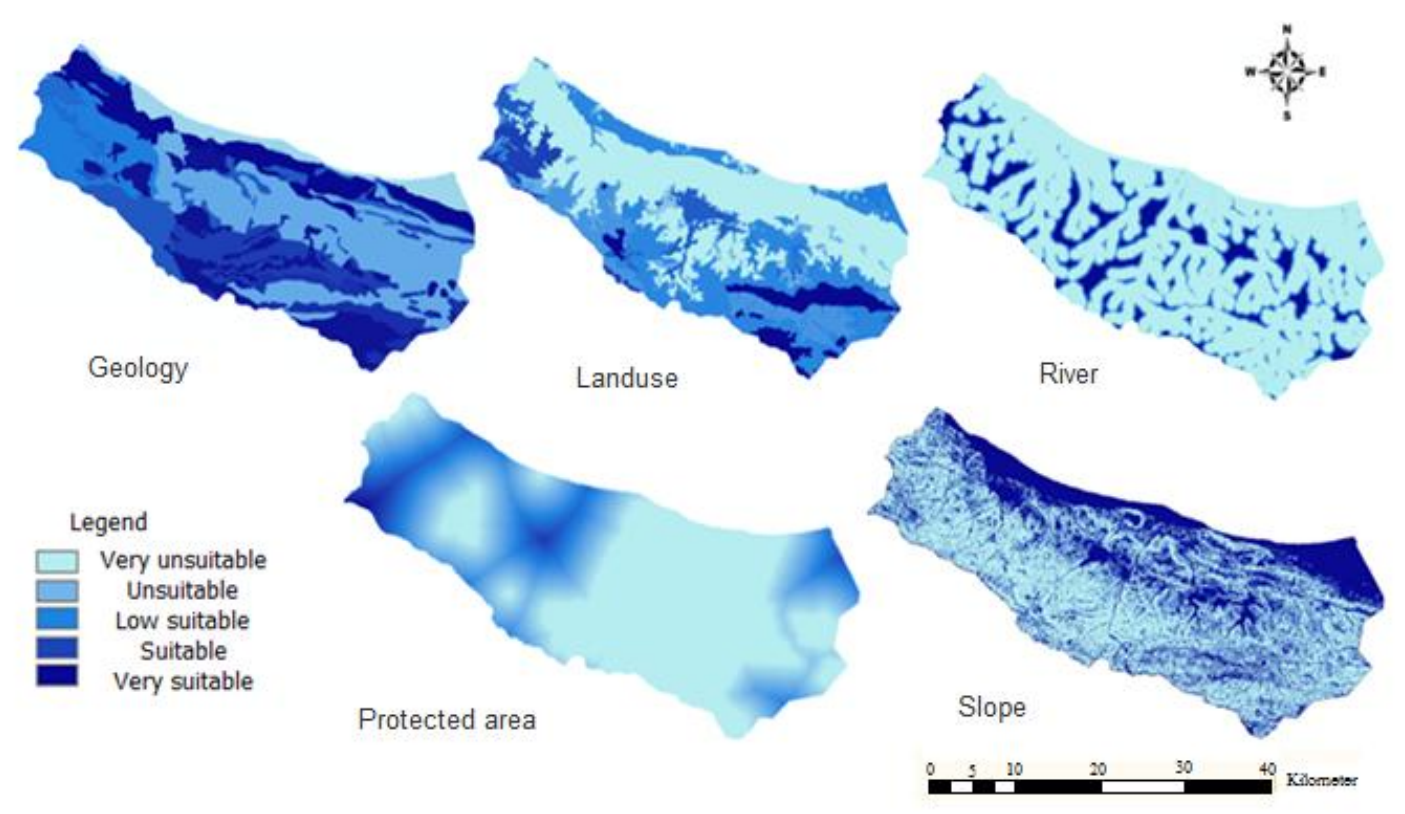

Figure 7. Some of the standardized maps in phase 2 according to fuzzy logic

\section{Discussion}

Unfortunately in Iran, similar to other developing countries, there have been few studies carried out on evaluating current landfill sites. Municipalities rarely consider the ecological properties of an area, adequately, in accordance to the governmental organizations and international standards and the pre-defined criteria before depositing the waste material at the edges of the cities and degrading the valuable natural ecosystems. Therefore, the applicable criteria are hardly used in most of the MSW landfill sites. Comparing the applied criteria indicated that all the criteria have some similar aspects in common. According to the previously studies, some parameters are joined in all methods. These common parameters have been considered in the present study. Parameters such as hydrology, distance form roads and airports and preserving special habitats are some of the factors taken into account in most of the methods due to their crucial significance. The studied parameters and their prioritization can be different based on the ecological characteristics. Choosing a set of effective parameters for selecting the location and evaluation of the landfill sites in relation to the environmental conditions of the studied area is critical and has a direct effect on prioritizing parameters (Sener, 2004). For instance, one study has shown that the highest prioritised parameters in landfill site selection are distance from urban and rural areas, surface water, geology, land use and fundamental instalments and roads, respectively (Khan and Anjaneyulu, 2003). In another study the priority of parameters was distance from geologic faults and the depth of earth, distance to the airports, distance to urban areas, distance to lakes, dams and slope of the soil, land use, paths network and in final run the least priority belonged to instalments and telecommunication (Delgado et al., 2008). In this study, preservation of the ecosystems of the vast water resources, both underground and surface, as well as the Caspian Sea was the preeminent concern. (Tajziehchi and Monavari, 2013) mentioned in their research that geographical features and special environment in this region are the main reasons for the complex landfill site sitting process. All of the considered criteria in this study and previously researches are 
to prevent land degradation and protect the environment. To evaluate the landfill sites in the studied area in the present research, which is situated in western part of Mazandaran province, noble approaches are required because of its special topographic conditions (closeness to the forest and the sea), high level of underground water and high rate of tourism (especially in spring and summer). Considering the importance of prioritizing the data layers in multi-criteria evaluation and defining the value of the layers based on their specific ecological conditions, the criteria and their importance can be changed. Therefore, locally criteria-Caspian landfill criteria-appropriate to the ecological condition of the area has been presented.

\section{Conclusion}

This research shows the incoherence in suitability status of the 10 current landfill sites in west area of Mazandaran province with using seven different landfill site sitting approaches. In second phase, the proposed Caspian Landfill Criteria with effective and native criteria has been used to determine the status and (un)suitabilty of the current landfills and the studied area. The suitability of the CLC (Caspian Landfill Criteria) model for landfill site sitting and evaluation of the current landfill sites were considered through field observations. Finally, only about $0.4 \%$ of the whole studied area was appropriate for landfilling. The most principal parts in the CLC model were the importance of the weights of the criteria and the preferred weights of them which in this research, distance to residential area parameter has the highest and slope has the least weight. As the findings of the present study have revealed, there are insufficient suitable areas in the western part of Mazandaran province for landfill site sitting. Furthermore, landfilling is not an appropriate approach for waste disposal in this region. There for other approaches should be considered for waste disposal with regard to the environmental characteristic of this specific region. The results of this study have been achieved using the same method applied for processing the consequent and phasic analysis in multi-criteria decision making in researches on locating and evaluating the landfill sites. The Caspian Landfill Criteria model with effective and native criteria has been used to determine the status of the current landfills and recognize the ruined areas, which are a good illustration of land degradation, in order to achieve an optimal management approach to convert the land into a sustainable natural ecosystem of the southern coast of the Caspian Sea.

\section{REFERENCES}

[1] Abdoli, M. (2005): A Recycling of Municipal Solid Wastes. - Tehran University, Iran.

[2] Adamcová, D., Vaverková, M. D., Bartoň, S., Havlíček, Z., Břoušková, E. (2016): Soil contamination in landfills: A case study of a landfill in Czech Republic. - Solid Earth 7(1): 239-247.

[3] Alanbari, M. A., Al-Ansari N., Jasim, H. K., Knutsson, S. (2014): Al-Mseiab Qadaa Landfill Site Selection Using GIS and Multicriteria Decision Analysis. - Engineering 6: 526-549.

[4] Aliowsati, F., Monavari, M., Omrani, G. A. (2013): The evaluation of Karaj municipal solid waste landfill site with local and regional screening. - Journal of Environmental Science and Tecnology 15(4): 86-96. 
[5] Baun, D. L., Christensen, T. H. (2004): Speciation of heavy metals in landfill leachate: a review. - Waste management \& Research 22(1): 3-23.

[6] Calvo, F, Moreno, B., Ramos, A., Zamorano, M. (2007): Implementation of a new environmental impact assessment for municipal waste landfill as tool for planning and decision-making process. - Renewable and Sustainable Energy Reviews 11(1): 98-115.

[7] Calvo, F, Moreno, B., Zamorano, M. S., Zanto M. (2005): Environmental diagnosis methodology for municipal waste landfills. - Waste Management 25: 768-79.

[8] Cassinari, C., Manfredi, P., Giupponi, L., Trevisan, M., Piccini, C. (2015): Relationship between hydraulic properties and plant coverage of the closed-landfill soils in Piacenza (Po Valley, Italy). - Solid Earth 6(3): 929-943.

[9] Chen, X-W., Wong, J. T-F., Mo, W-Y., Man, Y-B., Ng, C. W-W., Wong, M-H. (2016): Ecological Performance of the Restored South East New Territories (SENT) Landfill in Hong Kong (2000-2012). - Land Degradation and Development 27(6): 1664-1676.

[10] Christensen, T. H., Cossu, R., Stegmann, R. (1992): Landfilling of waste. - Leachate (1st Edn.). Taylor \& Francis, London.

[11] Davami, A. H., Moharamnejad, N., Monavari, S. M., Shariat, M. (2014): An Urban Solid Waste Landfill Site Evaluation Process incorporating GIS in Local Scale Environment: A Case of Ahvaz City, Iran. - International Journal of Environmental Research 8(4): 1011-1018.

[12] Davies, G. M, Pollard, L., Mwenda, M. D. (2010): Perceptions of land degradation, forest restoration and fire management: a case study from Malawi. - Land Degradation and Development 21(6): 546-556.

[13] Delgado, O. B., Mendosa, M., Granados, E. L., Geneletti, D. (2008): Analysis of land suitability for the sitting of inter-municipal landfills in the Cuitzeo Lake Basin, Mexico. Waste Management 28: 1137-1146.

[14] Diaz, L. F., Savage, G. M., Egerth, L. L. A. (2005): Internatives for the treatment and disposal of healthcare waste in developing countries. - Waste Management 25(6): 626-37.

[15] Dimitriou, F., Karaouzas, I., Saratakos, K., Zacharias, I., Bogdanos, K., Diapoulis, A. (2008): Ground water risk assessment at a heavily industrialised catchment and management. - Journal of Environmental Management 88(3): 526-538.

[16] Eastman, J. R. (2012): IDRISI 17.0 e Selva Edition. - Clark University, Clark Labs.

[17] Elahi, A., Samadyar, H. (2014): Municipal Solid Waste Landfill Site Selection Using Analytic Hierarchy Process Method for Tafresh Town. - Middle-East Journal of Scientific Research 22(9): 1294-1307.

[18] Eskandari, M., Homaee, M., Mahmoudi, S. (2012): An integrated multi criteria approach for landfill sitting in a conflicting environmental, economical and socio-cultural area. Waste Management 32(8): 1528-1538.

[19] Fallahzade, J., Hajabbasi, M. A. (2015): The effects of irrigation and cultivation on the quality of desert soil in central Iran. - Land Degradation \& Development 23(1): 53-61.

[20] Fatta, D., Papadopoulos, A., Loizidou, M. (1999): A study on the landfill leachate and its impact on the groundwater quality of the greater area. -Environmental Geochemistry and Health 21(2): 175-90.

[21] Farzaneh, G. (2003): The study of environmental impact assessment of solid waste landfill in west of Golestan Province. - The Environment (in Persian) 42: 59-65.

[22] Ghanbari, F., Aminsharee, F., Zaredar, N., Monavari, M. (2011): A new method for environmental site assessment of urban solid waste landfills. - Environmental Monitoring Assessment 184(3):1221-30.

[23] Gilardelli, F., Sgorbati, S., Citterio, S., Gentili, R. (2016): Restoring Limestone Quarries: Hayseed, Commercial Seed Mixture Or Spontaneous Succession. - Land Degradation and Development 27(2): 316-324.

[24] Guerrero, L .A., Maas, G., Hogland, W. (2013): Solid waste management challenges for cities in developing countries. - Waste Management 33(1): 220-232.

[25] Haigh, M., Reed, H., Flege, A., D'Aucourt, M., Plamping, K., Cullis, M., Woodruffe, P., Sawyer, S., Panhuis, W., Wilding, G., Farrugia, F., Powell, S. (2015): Effect of Planting 
Method on the Growth of Alnus glutinosa and Quercus petraea in Compacted Opencast Coal-Mine Spoils, South Wales. - Land Degradation and Development 26(3): 227-236.

[26] Hatzichristos, T., Giaoutzi, M. (2006): Landfill siting using GIS, Fuzzy logic and the Delphi method. - International Journal of Environmental Technology and Management 6(1-2): 218-231.

[27] Hernandez, A. J., Adarve Alcazar, M. J., Pastor, J. (1998): Some impact of urban waste landfills on Mediterranean soils. - Land degradation and development 9(1): 21-33.

[28] Heydarzadeh, N. (2001): Municipal solid waste landfill sitting, using geographic information systems to Environmental Engineering. - MSc thesis. Tarbiat Modarres University, Faculty of Engineering.

[29] Iranian Statistics Centre. (2010): General Census of Population and Housing of Mazandaran province.

[30] Kale, S. S., Kadam, A. K., Kumar, S., Pawar, N. (2010): Evaluating pollution potential of leachate from landfill site, from the Pune metropolitan city and its impact on shallow basaltic aquifers. - Environmental Monitoring and Assessment 162(1-4): 327-346.

[31] Kazemi, A., Younesi, H., Bahramifar, N. (2013): Assessment of the Variations in the composition of the leachate generated in open dumps in three provinces of the Caspian Sea region, Iran. - Iranian Journal of Toxicology 7(22): 907-914.

[32] Khan, Z., Anjaneyulu, Y. (2003): Selection of Hazardous Waste Damp Site Based on Parameters Effecting Soil Adsorption - a Case Study. - Environmental Geology 43(8): 986-990.

[33] Koshik, P., Dutta, A., Krishna, A. P. (2014): A comprehensive study on landfill site selection for Kolkata city, India. - Air and Waste Management Association 64(7): 846-861.

[34] Martínez-Murillo, J. F., Hueso-González, P., Ruiz-Sinoga, J. D., Lavee, H. (2016): ShortTerm Experimental Fire Effects in Soil and Water Losses in Southern of Spain. - Land Degradation and Development 27(5): 1513-1522.

[35] Mazandaran governor. (2014): .Mazandaran land use planning book. - Department of Planning Office.

[36] Meshkini, A., Shahabi, H., Zoghi, A. (2007): Town and urban identity. - Second international conference of superior city superior plan, Hamadan, Iran.

[37] Moeinaddini, M., Khorasani, N., Danehkar, A., Darvishsefat, A., Zienalyan, A. (2010): Sitting MSW landfill using weighted linear combination and analytical hierarchy process (AHP) methodology in GIS environment (case study: Karaj). - Waste Management 30(5): 912-920.

[38] Monavari, M., Arbab, P. (2005): The environmental evaluation of municipal solid waste landfills of the Tehran province. - Environmental Sciences 2(8): 1-8.

[39] Monavari, M., Shariat, M. (2000): Evaluation of landfill site selection standalards in Rasht. - Science and Technology 1(2): 27-34.

[40] Mor, S., Ravindra, K., Dahiya, R. P., Chandra, A. (2006): Leachate characterization and assessment of ground water pollution near municipal solid waste landfill site. Environmental Monitoring and Assessment 118(1-3): 435-456.

[41] Nema, A. K., Datta, M., Singh, R. K. (2009): A new system for ground water contamination hazard rating of landfills. - Journal of Environmental Management 91(2): 344-357.

[42] Novara, A., Gristina, L., Guaitoli, F., Santoro, A., Cerdà, A. (2013): Managing soil nitrate with cover crops and buffer strips in Sicilian vineyards. - Solid Earth 4: 255-262.

[43] Pallavicini, Y., Alday, J. G., Martínez-Ruiz, C. F. (2014):Factors affecting herbaceous richness and biomass accumulation patterns of reclaimed coal mines. - Land Degradation and Development. 26(3):211-217.

[44] Pereira, P., Cerdà, A., Lopez, A. J., Zavala, L. M., Mataix-Solera, J., Arcenegui, V., Misiune, I., Keesstra, S., Novara, A. (2016): Short-Term Vegetation Recovery After a Grassland Fire in Lithuania: The Effects of Fire Severity, Slope Position and Aspect. Land Degradation and Development 27(5): 1523-1534. 
[45] Quinonero-Rubio, J. M., Nadeu, E., Box-Fayos, C., De Vente, J. (2016): Evaluation of the effectiveness of forest restoration and check-dams to reduce catchment sediment yield. -Land Degradation and Development. 27(4):1018-1031.

[46] Rahim, A., Fazel, M. M. (2008): Pathological approach to achieve the desired eye view of the environment in 20 years. - Third National Conference on Waste Management and its role in urban planning. Tehran, Iran.

[47] Raman, N., Rayanan, S., (2008): Impact of solid waste effects on ground water and soil quality nearer to Pallavaram solid waste landfill site in Chennai. - Rasayan Journal 1(4): 828-836.

[48] Sadeghi, S. H. R., Gholami, L., Sharifi, E., Darvishan, A. K., Homaee, M. (2015): Scale effect on runoff and soil loss control using rice straw mulch under laboratory conditions. Solid Earth 6: 1-8.

[49] Salimi, M., Ebrahimi, A., Salimi, A. (2013): Evaluation of new location of Isfahan's sanitary landfill site with Oleckno method. - International Journal of Environmental Health 2: 33.

[50] Sener, B., Süzen, M. L., Doyuran, V. (2006): Landfill site selection by using Geographic Information systems. - 49(3): 376-388.

[51] Shahabi, H. (2008): Role of Geomorphic ingredient in Saqqez urbans surplus materials landfill site selection by using GIS models and Remote Sensing technique. - MSc thesis. University of Tehran, Iran.

[52] Sharholy, M., Ahmad, K., Mahmood, G., Trivedi, R. (2008): Municipal solid waste management in Indian cities - A review. - Waste Management 28(2):459-67.

[53] Shaylor, H., McBride, M., Harrison, E. (2009): Sources and impacts of contaminants in soil. - Cornell Waste Management Institute. Available at: http:// cwmi.css.cornell.edu.

[54] Sumathi, V. R., Natesan, U., Sarkar, C. (2008): GIS based approach for optimized sitting of municipal solid waste landfill. - Waste Management 28(11): 2146-2160.

[55] Sureshkumar, R., Nagarajan, M. (2017): Selection of alternative landfill site in Kanchipuram India by using GIS and Multi criteria decision analysis. - Applied ecology and Environmental Researches 15(1): 627-636.

[56] Tajziehchi, S., Monavari. S. M. (2013): Evaluation of municipal solid waste landfill in the Caspian sea coasts:Iran. - First International Conference on Environmental crisis and its solutions, Kish islan, Iran, 506-521.

[57] Voogd, H. (1983): Multi criteria Evaluations for Urban and Regional Planning. Princeton University, NJ, USA.

[58] Wang, L. (2007): Assessment of groundwater vulnerability to landfill leachate induced arsenic contamination in Maine. - US. Intro GIS Term Project Final Report, Department of Civil \& Environmental Engineering.

[59] Wong, J. T-F., Chen, X-W., Mo, W-Y., Man, Y-B., Ng, C. W-W., Wong, M-H. (2016): Restoration of Plant and Animal Communities in a Sanitary Landfill: A 10-Year Case Study in Hong Kong. - Land Degradation and Development 27(3): 490-499.

[60] Wong, M. H., Chan, Y. S. G., Zhang, C., Ng, C. W-W. (2016): Comparison of Pioneer and Native Woodland Species Growing on Top of an Engineered Landfill, Hong Kong: Restoration Programme. - Land Degradation and Development 27(3): 500-510.

[61] Yazdani, M., Monavari, M., Omrani, G. A., Shariat, M., Hosseini, M. (2013): The Evaluation of Municipal Landfill Sites in Northern Iran through Comparing BC Guideline and Iran Legislation. - Journal of Environmental Protection 4(8): 811-817.

[62] Yazdani, M., Monavari, M., Omrani, G. A., Shariat, M., Hosseini, M. (2015a): Landfill site suitability assessment by means of Geographic Information System Analysis. - Solid Earth 6: 945-956.

[63] Yazdani, M., Monavari, M., Omrani, G. A., Shariat, M., Hosseini, M. (2015b): Municipal solid waste open dumping, implication for land degradation. - Solid Earth Discussion 7: 1097-1118. 